Original Research Paper

\title{
Comparison of Molecular Markers ISSR, SSR and RFLP to Study the Genetic Variation of Strawberry Cultivars
}

\author{
${ }^{1}$ Ganies Riza Aristya, ${ }^{2}$ Rina Kasiamdari, ${ }^{3}$ Muhammad Fauzi Arif, ${ }^{3}$ Fitri Amalia and ${ }^{3}$ Rahma Dwi Pawestri \\ ${ }^{1}$ Laboratory of Genetics and Breeding, Faculty of Biology, Universitas Gadjah Mada, Yogyakarta, Indonesia \\ ${ }^{2}$ Laboratory of Plant Systematics, Faculty of Biology, Universitas Gadjah Mada, Yogyakarta, Indonesia \\ ${ }^{3}$ Freshgraduate Student of Faculty of Biology, Universitas Gadjah Mada, Yogyakarta, Indonesia
}

Article history

Received: 27-12-2018

Revised: 28-01-2019

Accepted: 19-03-2019

Corresponding Author:

Ganies Riza Aristya,

Laboratory of Genetics and

Breeding, Faculty of Biology,

Universitas Gadjah Mada,

Yogyakarta, Indonesia

Email: ganies_riza@ugm.ac.id

\begin{abstract}
Strawberry is grown in Indonesia because it has potential high economic value. The purpose of this study was to investigate relationship of phenetic lineage and genetic variations in 12 strawberry cultivars using three different molecular marker methods, including ISSR, SSR and RFLP. Five primers of ISSR markers were used and they generated 53 bands with 44 polymorphic DNA bands. Percentage of polymorphic using ISSR method was $83 \%$. Five primers of SSR markers were used and they gave 41 DNA bands with 36 polymorphic DNA bands. Percentage of polymorphic using SSR method was $87 \%$. Four primers of PCR-RFLP markers and 3 enzymes were used and they had 20 DNA bands with 9 polymorphic DNA bands. Percentage of polymorphic PCR-RFLP method was $45 \%$. Three dendrogram results based on each method indicated that Stroberi Hitam has smallest similarity index compared with other eleven cultivars. 'Californica' cultivar had the closest similarity with Stroberi Hitam. Data analysis of molecular character requires complementary and supporting data of other characters such as morphology, biochemistry and cytology so this will strengthen the lineage data of the organisms to be investigated. Molecular marker can be used as a good method for genetic variation analysis if it has some advantages such as high polymorphism, codominance and specific characteristics and wide distribution.
\end{abstract}

Keywords: Strawberry, Fragaria spp., Molecular Markers, Genetic Variation

\section{Introduction}

Strawberry (Fragaria spp.) is one of fruit plants grown almost all over the world because it has high economic value. In Indonesia, strawberry production increases from 19,132 tons in 2009 to 169,796 tons in 2012 but it decreased to 90,352 tons in 2013 and decreased again to 58,882 tons in 2014 (Directorate General of Horticulture of the Ministry of Agriculture, Indonesia, 2015). The decrease in strawberry production in Indonesia requires efforts to improve strawberry superior character in order to increase the strawberry productivity again. One of the efforts to improve strawberry superior character in Indonesia is made by more intensive plant breeding technique through study of genetic diversity. This is carried out to ensure that strawberry plant that has superior quality is available for cultivation.

The rapid development of DNA molecular marker technique has resulted in the increase of various techniques for genetic diversity analysis of an organism (Weising et al., 2005). Molecular marker data can be used to overcome the limitation of genetic variation analysis based on morphological, cytological, biochemical and physiological characters (Jonah et al., 2011). Some molecular markers such as Random Fragment Length Polymorphism (RFLP), Inter Simple Sequence Repeat (ISSR) and Simple Sequence Repeat (SSR) are efficient techniques to detect genetic diversity (Chakravarthi and Naravaneni, 2006). Analysis using molecular marker is relatively more effective in plants with high level of variety such as strawberry (Fragaria spp.). Several techniques have technical differences such as the amount of DNAs needed, cost, polymorphism level and complexity (Semagn et al., 2006).

The purpose of this study was to investigate relationship of phenetic lineage and genetic variations in 12 strawberry cultivars using different molecular markers such as ISSR, SSR and RFLP. 


\section{Materials and Methods}

\section{Plant Materials}

Twelve strawberry cultivars obtained from Indonesian Citrus and Subtropical Fruits Research Institute (ICSFRI), Malang, East Java and Strawberry Agrotourism in Banyuroto Village, Magelang, Central Java (Table 1).

\section{DNA Isolation}

About 12 Fifth leaves aged 3 to 4 weeks from each cultivar were cut using scissors and then inserted in sample box in cold condition. Samples were stored at $-20^{\circ} \mathrm{C}$. DNA was extracted from strawberry leaves of each cultivar using modified CTAB method (Doyle and Doyle, 1990).

Table 1: Strawberry cultivars used in the study

\begin{tabular}{lll}
\hline No. & Cultivars & Origin of sample \\
\hline 1 & 'Aerut' & ICSFRI, Malang \\
2 & 'Berastagi' & ICSFRI, Malang \\
3 & 'Dorit' & ICSFRI, Malang \\
4 & 'Deeprose' & ICSFRI, Malang \\
5 & 'Festival' & ICSFRI, Malang \\
6 & 'Oso Grande' & ICSFRI, Malang \\
7 & 'Oso Purbalingga' ICSFRI, Malang \\
8 & 'Californica' & Banyuroto, Magelang \\
9 & 'Earlybrite' & Banyuroto, Magelang \\
10 & 'Rosalinda' & Banyuroto, Magelang \\
11 & 'Tristar' & Banyuroto, Magelang \\
12 & Stroberi Hitam & Banyuroto, Magelang \\
\hline
\end{tabular}

DNA purity was calculated using spectrophotometer and DNA was stored at $-20^{\circ} \mathrm{C}$. The isolated DNA was then amplified using Polymerase Chain Reaction (PCR).

\section{DNA Amplification}

The DNA of each successfully isolated strawberry cultivar then used as template for amplification process. DNA amplification was performed with 3 different kinds of molecular markers namely ISSR, SSR and PCRRFLP. Molecular markers used for ISSR (Debnath et al., 2008), SSR (Gil-Ariza et al., 2006) and PCR-RFLP (Kunihisa et al., 2006) are shown in Table 2.

In ISSR method, DNA amplification was done on pre-denaturation temperature of $95^{\circ} \mathrm{C}$ for 10 minutes, denaturation temperature of $95^{\circ} \mathrm{C}$ for 30 seconds, annealing temperature of $43-49^{\circ} \mathrm{C}$ for 30 seconds, elongation temperature of $72^{\circ} \mathrm{C}$ for 2 minutes and post elongation temperature of $72^{\circ} \mathrm{C}$ for 5 minutes. In SSR method, DNA amplification was performed on predenaturation temperature of $95^{\circ} \mathrm{C}$ for 3 minutes, denaturation temperature of $95^{\circ} \mathrm{C}$ for 30 seconds, annealing temperature of 52 and $54^{\circ} \mathrm{C}$ for 30 seconds, elongation temperature of $72^{\circ} \mathrm{C}$ for 1 minute and post elongation temperature of $72^{\circ} \mathrm{C}$ for 1 minute. In RFLP method, DNA amplification was carried out on predenaturation temperature of $95^{\circ} \mathrm{C}$ for $3 \mathrm{~min}$, denaturation temperature of $95^{\circ} \mathrm{C}$ for $30 \mathrm{sec}$, annealing temperature of 54 and $58^{\circ} \mathrm{C}$ for $30 \mathrm{sec}$, elongation temperature of $72^{\circ} \mathrm{C}$ for 1 min and post elongation temperature of $72^{\circ} \mathrm{C}$ for $1 \mathrm{~min}$.

Table 2: Names and sequences of Primers used for each technique

\begin{tabular}{|c|c|c|c|c|}
\hline \multirow{2}{*}{$\overline{\text { ISSR }}$} & \multicolumn{2}{|c|}{ Primers } & \multicolumn{2}{|l|}{ Primer Sequence $5^{\prime}-3^{\prime}$} \\
\hline & \multicolumn{2}{|c|}{ UBC-817 } & & CACACACACACACACAA \\
\hline & \multicolumn{2}{|c|}{ UBC-823 } & & ТСТСТСТСТСТСТСТСС \\
\hline & \multicolumn{2}{|c|}{ UBC-827 } & & ACACACACACACACACG \\
\hline & \multicolumn{2}{|c|}{ UBC-834 } & & AGAGAGAGAGAGAGAGYT \\
\hline & \multicolumn{2}{|c|}{ UBC-876 } & & GATAGATAGACAGACA \\
\hline \multirow[t]{10}{*}{ SSR } & \multicolumn{2}{|c|}{ ChFaM01 } & Forward & GGAGATTATGCACAAAATATAGAGA \\
\hline & & Reverse & CCAGAACTCCATCAGCCTCT & \\
\hline & \multicolumn{2}{|c|}{ ChFaM04 } & Forward & CCCAGCATATACTTTGCCGTA \\
\hline & & Reverse & TССТTТСТТСАТССССТССТ & \\
\hline & \multicolumn{2}{|c|}{ ChFaM07 } & Forward & AATATATTACTCATCCAATCTTGTC \\
\hline & & Reverse & AGATGGAGGGCTTGGAAGTT & \\
\hline & \multicolumn{2}{|c|}{$\mathrm{ChFaM} 23$} & Forward & AGGAGAAGACCGGCTGTGTA \\
\hline & & Reverse & TGCCTATAGCTGTGGCTGTG & \\
\hline & \multicolumn{2}{|c|}{ ChFaM29 } & Forward & ACTTCATCGCCAGAATGGTC \\
\hline & & Reverse & \multicolumn{2}{|l|}{ GCCATTCAATACACAATCCAA } \\
\hline \multirow[t]{9}{*}{ RFLP } & \multirow[t]{2}{*}{ CT12 } & Forward & \multicolumn{2}{|c|}{ GTCAAACCTCTCACGAAACCACT } \\
\hline & & Reverse & \multicolumn{2}{|c|}{ GTTRCTAAGAAAATGAAAGAGCTGATG } \\
\hline & \multirow[t]{2}{*}{ OLP } & Forward & \multicolumn{2}{|c|}{ TGTGTCCAAAACCGATCAGTATTGC } \\
\hline & & Reverse & \multicolumn{2}{|c|}{ TCTTTCAGAGTGGTACGTACCCC } \\
\hline & \multirow[t]{2}{*}{$\mathrm{F} 3 \mathrm{H}$} & Forward & \multicolumn{2}{|l|}{ TAATAGGGTCTAGGTGCGTGG } \\
\hline & & Reverse & \multicolumn{2}{|l|}{ GAGTTCACTACKGCCTGGTGATC } \\
\hline & \multirow[t]{3}{*}{ APX } & Forward & \multicolumn{2}{|l|}{ GTGGTCACACCTTGGTGC } \\
\hline & & Reverse & \multicolumn{2}{|l|}{ AGTATAATATTTAAGCAG $\backslash$} \\
\hline & & & \multicolumn{2}{|l|}{ AATGCAGACTTC } \\
\hline
\end{tabular}


Table 3: Restriction Enzymes used and its cut-off point

\begin{tabular}{|c|c|c|c|}
\hline No. & Restriction enzymes & Cut-Off point & Incubation temperature $\left({ }^{\circ} \mathrm{C}\right)$ \\
\hline 1 & TaqI & $5^{\prime} \downarrow$ GATC 3' & 37 \\
\hline 2 & $M l u \mathrm{I}$ & $\begin{array}{l}5^{\prime} \mathrm{A} \downarrow \text { CGCG T } 3^{\prime} \\
3^{\prime} \mathrm{T} \text { GCGC } \uparrow \mathrm{A} 5^{\prime}\end{array}$ & 37 \\
\hline 3 & TaqI & $\begin{array}{l}5^{\prime} \mathrm{T} \downarrow \mathrm{CG} \text { A } 3^{\prime} \\
3^{\prime} \mathrm{A} \text { GC } \uparrow \mathrm{T} 5^{\prime}\end{array}$ & 60 \\
\hline
\end{tabular}

All methods used the denaturation, annealing and elongation phases repeatedly as much as 40 cycles. SSR amplification results were separated using 6\% polyacrylamide gel. In PCR-RFLP, the amplified DNAs were cut using restriction enzyme (Table 3) with different incubation temperatures (Table 3 ).

\section{Data Analysis}

The size of amplified DNA was determined using $100 \mathrm{bp}$ and $20 \mathrm{bp}$ markers (Promega). Binary matrix was made based on the bands of amplified DNA. The visualized bands were rated as (1) and non-visualized bands were rated as $(0)$. The data were then prepared with Microsoft Excel 2013 software. Dendrogram construction was made using MVSP 3.1 software. Similarity Index was calculated using Percent Similarity method to estimate relationship among accessions. Dendrogram cluster was made using Unweighted Pair Group Method with Arithmetic Means (UPGMA).

\section{Results and Discussion}

Five primers of ISSR molecular markers generated 53 DNA bands, 9 of which were monomorphic DNA bands and the other 44 were polymorphic DNA bands (Fig 1). Percentage of the primer of polymorphic ISSR molecular marker was $83 \%$. The more parts of DNA genomes complementary to the primer, the more DNA bands are produced. Five primers of SSR molecular markers generated 41 DNA bands, 5 of which were monomorphic DNA bands and the other 36 were polymorphic DNA bands. Percentage of polymorphic SSR primers was $87 \%$. Furthermore, 4 primers of PCRRFLP molecular markers and 3 enzymes generated 20 DNA bands, 9 of which were monomorphic DNA bands and the other 11 were polymorphic DNA bands (Fig. 3). Percentage of polymorphic RFLP primers was $45 \%$.

Table (4) indicates that SSR molecular markers have the highest polymorphic percentage than ISSR and PCRRFLP. This is because SSR molecular markers are codominant and can distinguish homozygous and heterozygous individuals. SSR markers can amplify DNA sequences at a locus by tandem consisting of 1 to 6 bp repeatedly. A very abundant amount of SSRs in both eukaryotic and prokaryotic organisms and the number of its repetition show genetic difference or polymorphism level between individuals. SSR is found in both coding and non-coding DNA in a genome but more SSRs are found in non-coding region of DNA (Guan et al., 2013). Regarding to PCR-RFLP band cutting results, polymorphism percentage found here was the lowest compared with other markers. This is because PCRRFLP only amplified certain locus on DNA fragment of an individual. The resulting polymorphism also derived from the difference in certain sequences on the locus detected by restriction enzyme cutting results.

Regarding to the similarity index of ISSR markers, 'Oso Grande' and 'Oso Purbalingga' have similarity index of $95.385 \%$, this is because 'Oso Purbalingga' cultivar represents 'Oso Grande' cultivar derived from Californica cultivated in Purbalingga, Central Java, so both have the highest similarity index. A slight difference in 'Oso Grande' and 'Oso Purbalingga' cultivars is caused by environmental adaptation in tropical region of Purbalingga, Central Java. In similarity index of $90.382 \%$, 'Oso Grande' cultivar is clustered with 'Earlybrite', while in similarity index of $89.121 \%$, it is clustered with 'Festival' because these cultivars have 'Rosalinda' parent. According to Chandler (2000), 'Festival' is the crossbreed between 'Rosalinda' and 'Oso Grande' while 'Earlybrite' is cultivar derived from the crossbreed between 'Rosalinda' and 'FL 90-38' on a research conducted in Florida.

Based on RFLP markers, the cultivars are clustered based on the origin of each cultivar. This relates to the nature of genetic material inheritance from the parent to its breed. 'Oso Grande,' 'Oso Purbalingga', 'Aerut', 'Brastagi', 'Californica', 'Earlybrite', 'Dorit', 'Deeprose', 'Rosalinda' and 'Tristar' Strawberries can be clustered into one phenetic cluster as the fragments of cutting results have similarity value of $96.02 \%$. This can be associated with the origin of all cultivars. All of the cultivars are individuals belonging to $F$. x ananassa species. $F$. x ananassa is a hybrid of crossbreed between $F$. virgiana species from North American and $F$. chiloensi species from Chile. This shows that resistance gene sequence pattern of such ten cultivars is only slightly different from the restriction enzyme fragments used. The possibility of small difference in these cultivars is environmental factor. All primer pairs used in this study amplified gene that acts in resistance mechanism of pathogen attack and environmental stress. Extreme environmental stress may cause genetic mutation in the form of insertion and deletion. 'Californica' strawberry is different from the other ten cultivars because it only has fragment similarity of $92.02 \%$. 
Table 4: DNA polymorphisms generated by ISSR, SSR and RFLP markers

\begin{tabular}{lllll} 
Molecular & Number of & Mono-morphic & Poly- morphic & Percentage of \\
Marker & DNA Bands & DNA Bands & DNA Bands & Poly-morphism \\
\hline ISSR & 53 & 9 & 44 & $83 \%$ \\
SSR & 41 & 5 & 36 & $97 \%$ \\
RFLP & 20 & 11 & 9 & $45 \%$ \\
\hline
\end{tabular}
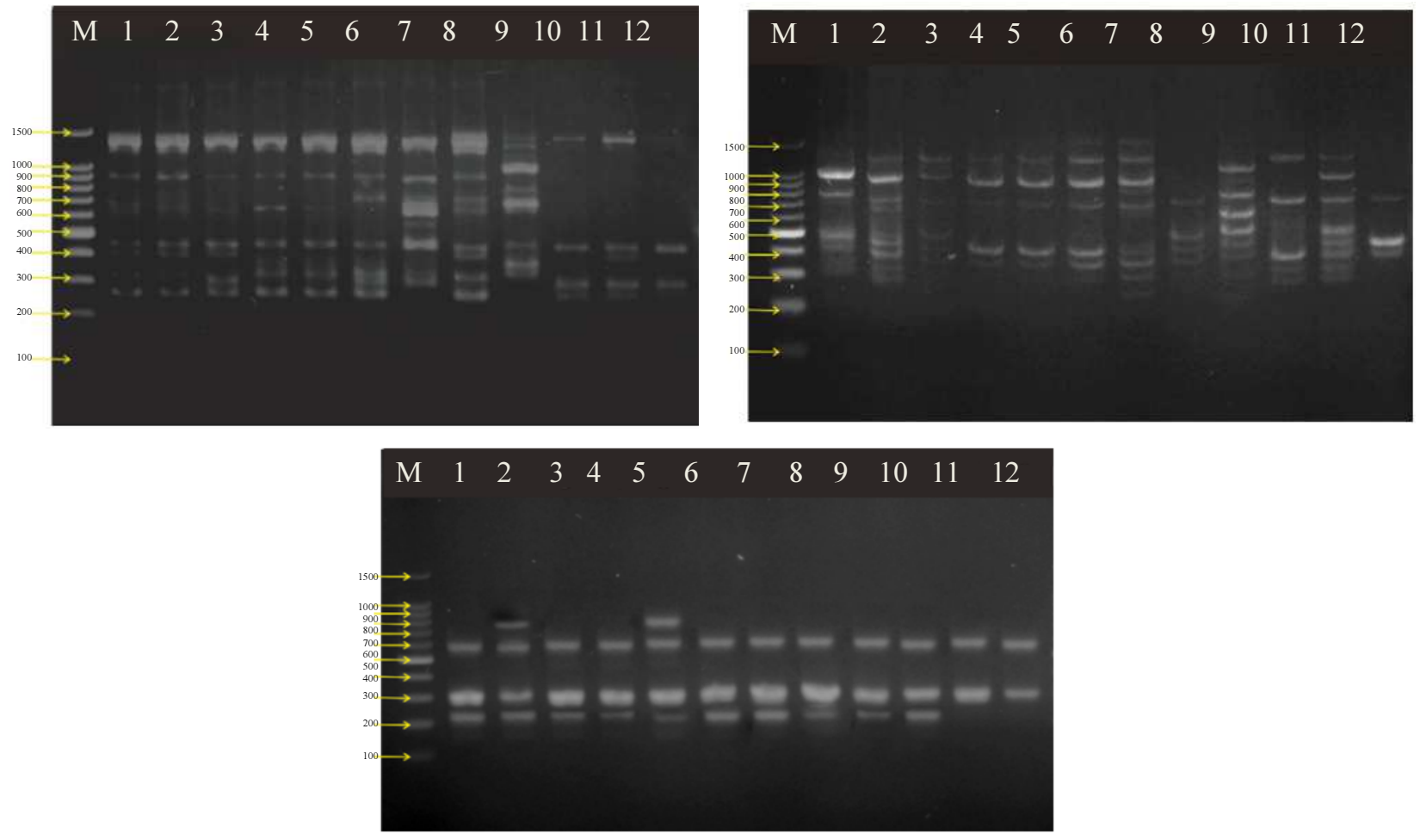

Fig. 1: Electrophoresis of 12 samples of strawberry (Fragaria spp.) cultivar using ISSR markers (a) UBC 823 primer (b) UBC 817 primer and (c) UBC 876 primer

Stroberi Hitam only has similarity index value of $77.47 \%$ of the other eleven cultivars. Both are different because they are classified into different species. Stroberi Hitam comes from F. moschata species while Californica Cultivar comes from $F$. vesca species. The species difference expectedly makes the amplified fragments in the four primers are also different. The twelve strawberry cultivars with RFLP markers were clustered based on the number of ploidy of each cultivar. Hancock et al. (2008) stated that the Aerut, Brastagi, Festival, Tristar, Earlybrite, Dorit, Deeprose, Rosalinda, Oso Grande and Oso Purbalingga Cultivars are octaploid individuals $(2 n=8 x=56)$. Californica cultivar that is diploid individual $(2 \mathrm{n}=2 \mathrm{x}=16)$ is different from the other ten cultivars, while Stroberi Hitam which is the most different cultivar from the other eleven cultivars is hexaploid individual $(2 n=6 x=48)$. Ploidy difference among these cultivars is expectedly due to allopolyploidization event. Allopolyploidization is hybridization event between two different species, which are still closely associated, resulting in the breed (Janick and Moore, 1996).
The SSR markers showed that 'Oso Grande', 'Oso Purbalingga', 'Rosalinda', 'Festival', 'Tristar' and 'Earlybrite' strawberry cultivars are clustered into one cluster namely B3 with similarity value of $75.34 \%$. This result is supported by research conducted by Chandler et al. $(1997 ; 2000)$, reported that the 'Earlybrite', 'Oso Grande', 'Rosalinda' and 'Festival' strawberry cultivars have the same parent namely 'Pajaro' cultivar (Fig. 2). 'Dorit', 'Rosalinda', 'Aerut' and 'Berastagi' cultivars were clustered with similarity value of $73 \%$. 'Aerut' and 'Berastagi' cultivars have high similarity index of $82.93 \%$.

The results of dendrogram based on each molecular marker (Fig. 4) show that Stroberi Hitam has the smallest similarity index than the other eleven cultivars, while 'Californica' cultivar has the closest similarity with Stroberi Hitam. Stroberi Hitam is classified as $F$. Moschata species, while 'Californica' cultivar is classified as $F$. vesca species. Both are not hybrid species of crossbreed result like the other ten cultivars. 
Cytological data showed that $F$. moschata has hexaploid chromosomes, while $F$. vesca has diploid chromosomes and $F$. x ananassa has octaploid chromosomes (Hancock et al., 2008). Other cultivars such as 'Oso Grande', 'Oso Purbalingga', 'Rosalinda', 'Deeprose', 'Dorit', 'Earlybrite', 'Tristar', 'Festival', 'Brastagi' and 'Aerut' are classified in $F$. $\mathrm{x}$ ananassa species. This strawberry cluster is different or separated based on the number of Stroberi Hitam chromosomes ( $F$. moschata) classified as hexaploid strawberry $(2 \mathrm{n}=6 \mathrm{x}=42)$, while 'Californica' cultivar ( $F$. vesca) is classified as diploid strawberry $(2 \mathrm{n}=14)$ and the cultivars of 'Dorit', 'Tristar', 'Aerut', 'Brastagi', 'Deeprose', 'Festival', 'Oso Grande', 'Oso Purbalingga', 'Earlybrite' and 'Rosalinda' (F. x ananassa) are classified as strawberry with octoploid chromosomes $(8 \mathrm{n}=56)$ (Darrow, 1966; Nathewet et al., 2010). According to Singh (2010), a taxon is said to belong to one genus if it has similarity index of $\geq 65 \%$ and $\geq 85 \%$ for species and the greater the similarity index the closer the lineage among varieties or cultivars. A variety or cultivar is said to have close similarity or lower level of diversity and variation if it has similarity level of $\geq 85 \%$.
Difference in the number of strawberry ploidy can be caused by hybridization among species with different genomes causing the difference in number of chromosomes or commonly called as allopolyploid. Allopolyploid leads to phenotypic change caused by the transfer of gene among species and chromosome substitution in order to acquire new or combined characteristics of both species. The low similarity of $F$. moschata, $F$. vesca and $F$. x ananassa is also caused by morphological difference of the three species. F. moschata has blackish red colored fruit, while $F$. vesca and $F$. x ananassa have bright red colored fruit (Janick and Moore, 1996).

Data analysis of molecular characters requires complementary and supporting data of other characters such as morphology, biochemistry and cytology in order to strenghten the lineage data of the organisms to be studied. Molecular markers can be used as the effective and efficient method based on the genotype of an organism that is more stable and is not easily affected by the environmental factors (Benor et al., 2008). Molecular markers can be used as good method for genetic variation analysis if it has several advantages such as high polymorphism, codominance and specific characteristics and wide distribution.
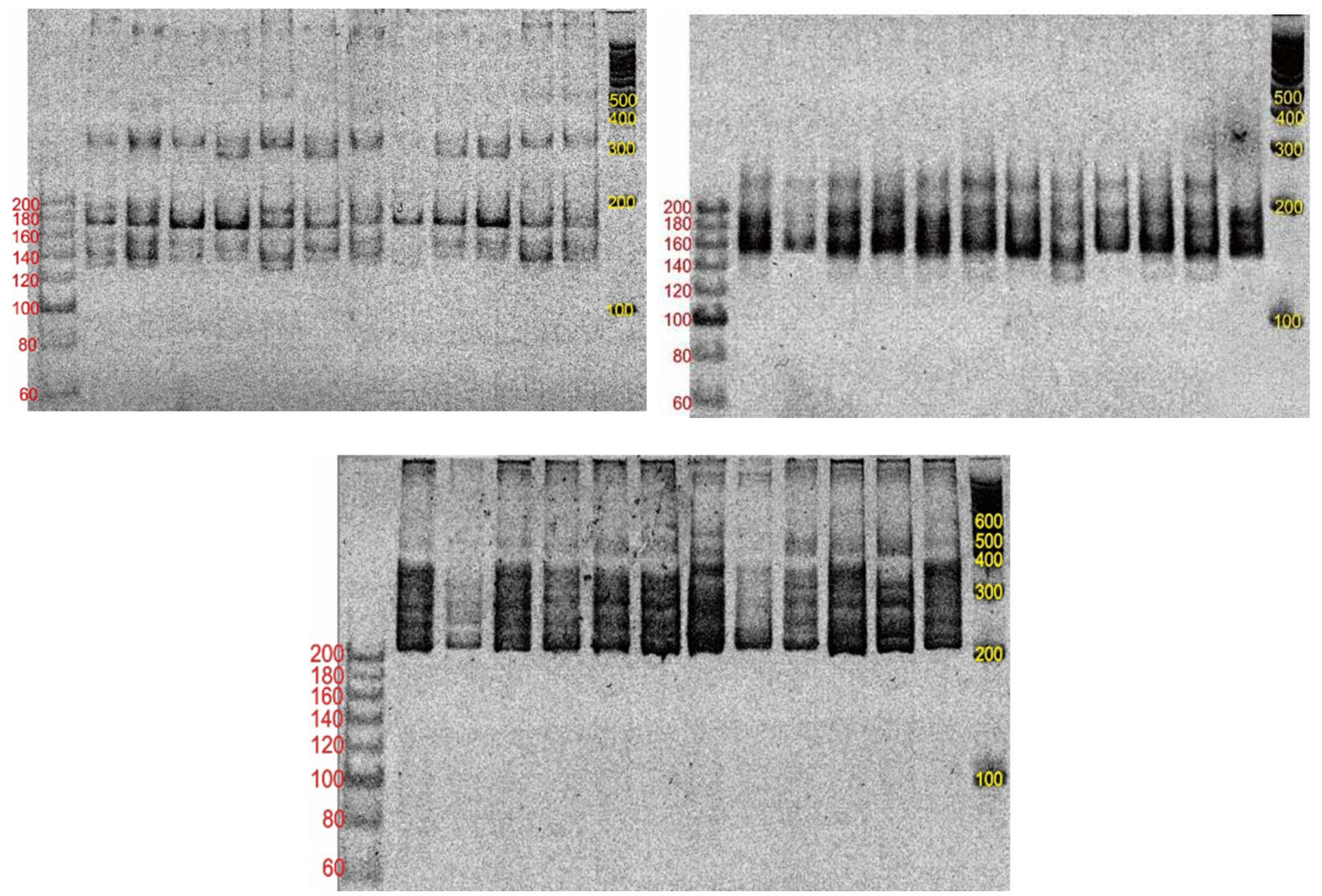

Fig. 2: Electrophoresis of 12 samples of strawberry (Fragaria spp.) cultivar using SSR markers (a) ChFaM04 primer (b) ChFaM07 primer and (c) ChFaM01 prime 

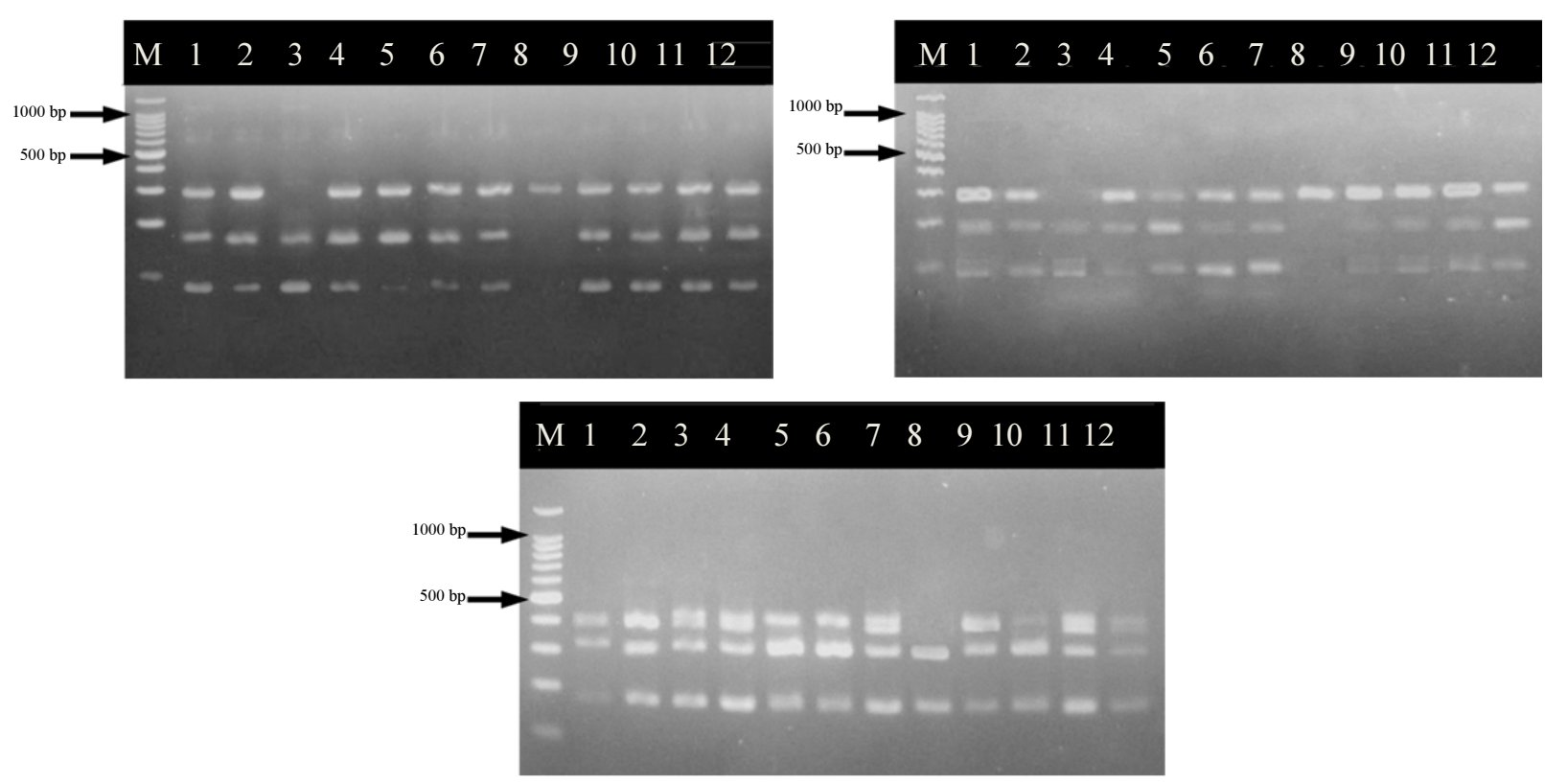

Fig. 3: Electrophoresis of 12 samples of strawberry (Fragaria spp.) cultivar using PCR-RFLP cutting result (a) CTI2-MluI 4 primer, (b) CTI2-MboI primer and (c) APx-TaqI primer

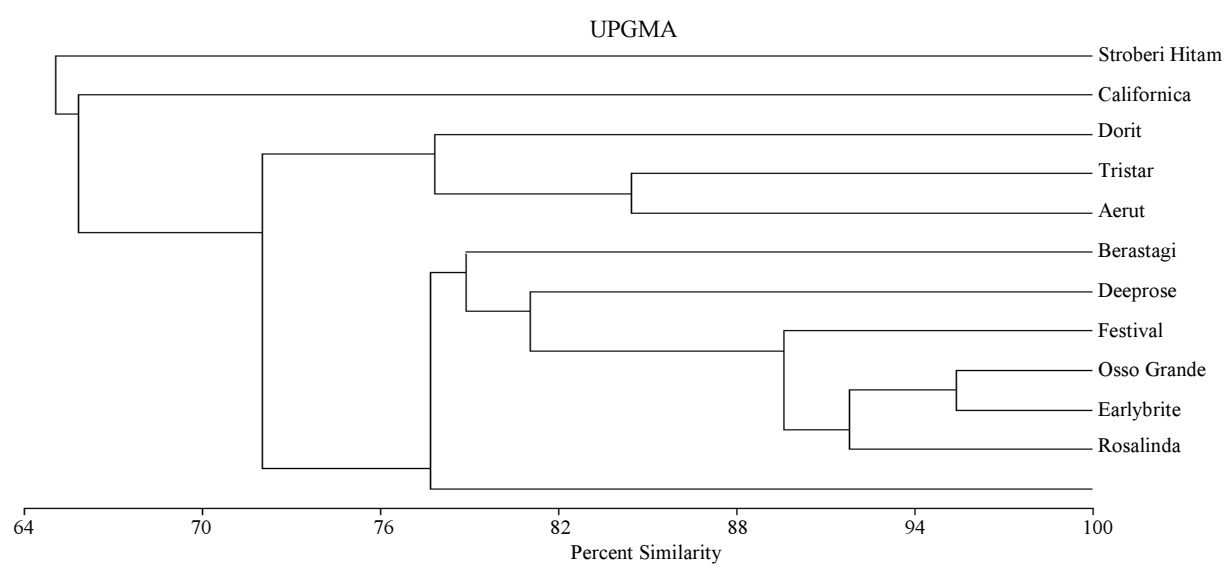

(a)

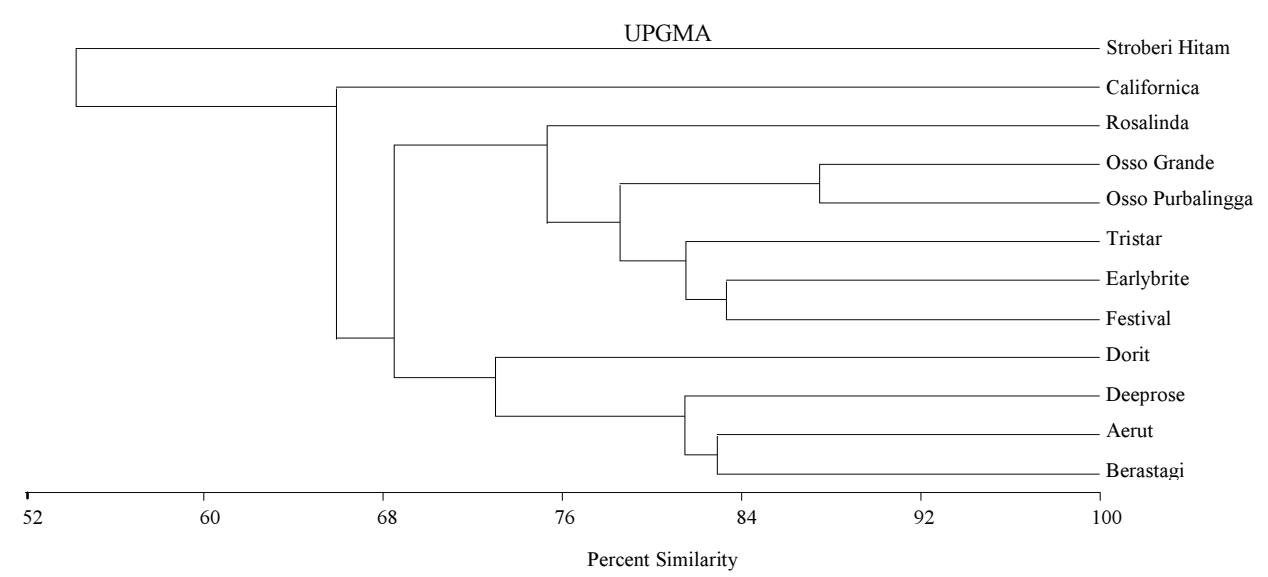

(b) 


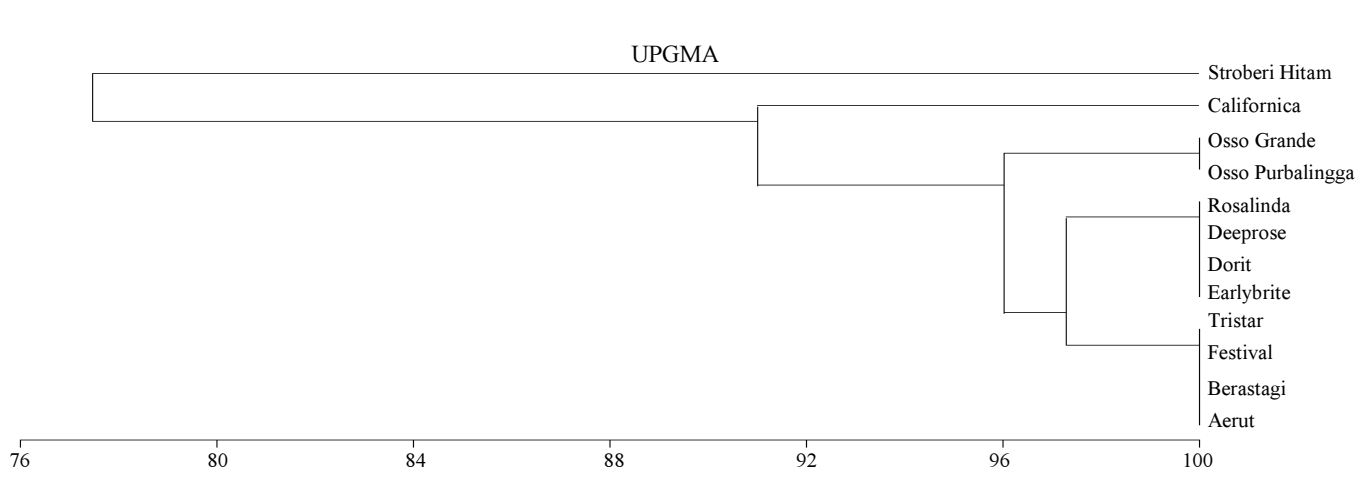

(c)

Fig. 4: Dendrogram results of 12 strawberry cultivars of (a) ISSR, (b) SSR and (c) RFLP

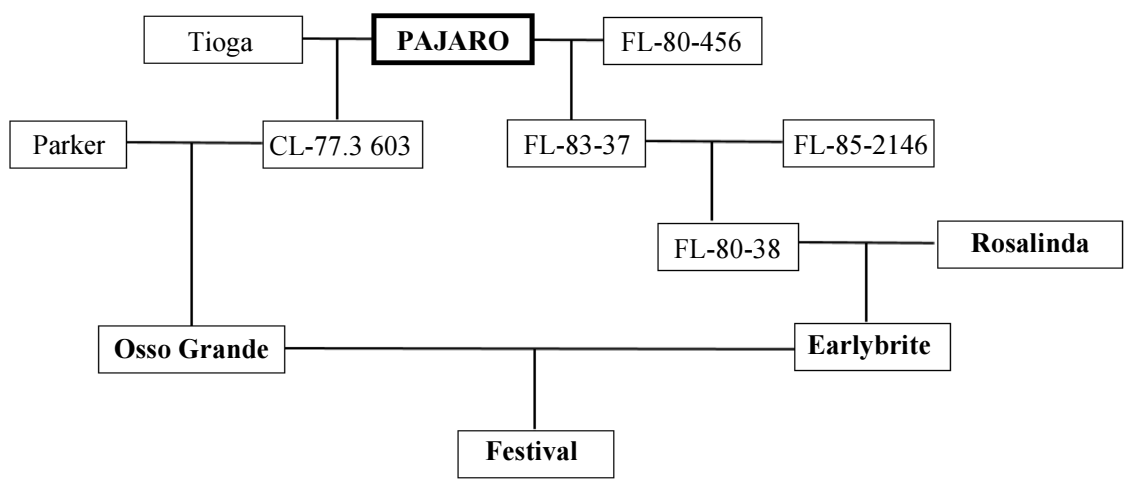

Fig. 5: Diagram of the lineage of Oso Grande, Earlybrite, Rosalinda and Festival strawberry cultivars (Voth et al., 1989; Chandler, 1997; 2000)

\section{Conclusion}

Stroberi Hitam is the most different cultivar compared with the other eleven cultivars based on the three molecular markers. Data analysis of molecular characters requires complementary and supporting data of other characters such as morphology, biochemistry and cytology in order to strenghten the lineage data of the organisms studied. Molecular markers can be used as the effective and efficient method based on the genotype of an organism that is more stable and is not easily affected by the environmental factors.

\section{Acknowledgement}

We are extremely grateful to the Ministry of Research, Technology and Higher Education of the Republic of Indonesia for the grant and financial support through Hikom grant.

\section{Funding Information}

This research was totally funded by the Ministry of Research, Technology and Higher Education of the Republic of Indonesia, 2275/UN.1.P.III/DIT-LIT/LT/2017.

\section{Ethics}

This article is original and contains unpublished material. The corresponding author confirms that all of the other authors have read and approved the manuscript and no ethical issues involved.

\section{References}

Benor, S., M. Zhang, Z. Wang and H, Zhang, 2008. Assessment of genetic variation in tomato (Solanum lycopersicum L.) inbred lines using SSR molecular markers. J. Genetics Genomics, 35: 373-379. DOI: 10.1016/S1673-8527(08)60054-5

Chakravarthi, B.K. and R. Naravaneni, 2006. SSR marker based DNAfingerprinting and diversity study in rice (Oriza sativa L.). African J. Biotechnology, 5: 684-688.

Chandler, C.K., D.E. Legard and C.A. Sims, 1997. 'Rosa Linda' strawbeny. Horticultural Sci., 32: 1134-1135.

Chandler, C.K., D.E. Legard, D. Dunigan, T.E. Crocker and C.A. Sims, 2000. Strawberry 'Festival', Strawberry. Horticultural Sci., 7: 1366-1367. 
Darrow, G.M., 1966. Strawberry: History, breeding and physiology. New England Institute for Medical Research, Canada, pp: 139-141.

Debnath, S.C., S. Khanizadeh, A.R. Jamieson and C. Kempler, 2008. Inter Simple Sequence Repeat (ISSR) markers to assess genetic diversity and relatedness within strawberry genotypes. Canada J. Plant Sci., 88: 313-322. DOI: 10.4141/CJPS07088

Direktorat Jenderal Hortikultura Kementerian Pertanian, 2015. Statistik Produksi Hortikultura Tahun 2014. Direktorat Jenderal Hortikultura Kementerian Pertanian, Jakarta, Indonesia.

Doyle, J.J. and J.L. Doyle, 1990. Isolation of plant DNA from fresh tissue. Focus, 12: 13-15.

Gil-Ariza, D.J., I. Amaya, M.A. Botella, J. Muñoz Blanco and J.L. Caballero et al., 2006. EST-derived polymorphic microsatellites from cultivated strawberry (Fragaria $\times$ ananassa) are useful for diversity studies and varietal identification among Fragaria species. Molecular Ecology Notes. DOI: $10.1111 /$ j.1471-8286.2006.01489.x

Guan, L., J.F. Huang, G.Q. Feng, X.W. Wang and Y. Wang et al., 2013. Survey of simple sequence repeats in woodland strawberry (Fragaria vesca). Genetics Molecular Res., 12: 2637-2651. DOI: $10.4238 / 2013$.July.30.3

Hancock, J.F., T.M. Sjulin and G.A. Lobos, 2008. Temperate fruit crop breeding. Springer, Michigan. pp: 393-02.
Janick, J. and J. N. Moore, 1996. Fruit Breeding. John Wiley and Sons, New York, pp: 422.

Jonah, P.M., L.L. Bello, O. Lucky, A. Midau and S.M. Moruppa, 2011. The importance of molecular markers in plant breeding programmes. Global J. Sci. Frontier Res., 11: 1-9.

Kunihisa, M., N. Fukino and S. Matsumoto, 2006. Development of PCR-RFLP marker on strawberry and the identification of cultivars and their progeny. Acta Hort, 708: 517-521.

Nathewet, P., K.E. Hummer, T. Yanagi, Y. Iwatsubo and K. Sone, 2010. Karyotype analysis in octoploid and decaploid wild strawberries in Fragaria (Rosaceae). Cytologia, 75: 277-288.

DOI: $10.1508 /$ cytologia.75.277

Semagn, A., Å. Bjørnstad and M.N. Ndjiondjop, 2006. An overview of molecular marker methods for plants. African J. Biotechnol., 5: 2540-2568.

Singh, G., 2010. Plant Systematics : An Intergrated Approach. CRC Press, Boca Raton. pp: 10-11.

Voth, V., S. Ana, S. Royce, Bringhurst and Davis, 1989. Strawberry plant called "Osso Grande". United States Patent.

Weising, K., H. Nybom, K. Wolf and G. Kahl, 2005. DNA Fingerprinting in Plants: Principles, Methods and Applications, 2nd Edn., Taylor and Francis Group, NW Boca Raton, pp: 30-41. 